https://nv.nltu.edu.ua

https://doi.org/10.15421/40290625

ISSN 2519-2477 (online)

Article received 05.05.2019 $\mathrm{p}$.

Article accepted 22.06.2019 p.

$@ \bowtie$ Correspondence author

N. K. Lysa

УДК 004.942

Л. С. Сікора' ${ }^{1}$ Н. К. Лиса', В. І. Сабат', Б. І. Федина', В. І. Кунченко-Харченко

${ }^{1}$ Начіональний університет "Львівська політехніка", м. Львів, Украӥна

${ }^{2}$ Українська академія друкарства, м. Львів, Украӥна

${ }^{3}$ Черкаський державний технологічний університет, м. Черкаси, Украйна

\title{
ЛАЗЕРНІ ТА ІНФОРМАЦЙНІ ТЕХНОЛОГІЇ КОНТРОЛЮ ДИНАМІЧНИХ ЗМІЩЕНЬ ПРОСТОРОВИХ СТРУКТУР ОБ'ЄКТІВ ЗА ДІЇ АКТИВНИХ ТЕХНОГЕННИХ І ПРИРОДНИХ ЧИННИКІВ РИЗИКУ АВАРІЙ
}

\begin{abstract}
На сучасному етапі розвитку науки для технологічних і техногенних енергоактивних систем вироблено системні методи
\end{abstract} ідентифікації структури, динаміки, оцінення ризику, тоді як для просторових об'єктів цю проблему повною мірою не вирішено. Це стосується будівництва та експлуатації таких об'єктів з просторово розподіленою структурою, як мости, великі павільйони, висотні будинки, агрегатні лінії на спільному фундаменті для кольорового друку, які піддаються великим динамічним неоднорідним за потужністю навантаженням, що діють упродовж тривалого часу експлуатації. Їх руйнація при сукупній дії динамічних і статичних неоднорідних потокових у часі чинників великої енергетичної потужності, призводить до аварій і людських втрат. Основний чинник, який призводить до когнітивних помилок у проектуванні просторових конструкцій, $є$ те, що фахівці у процесі розроблення проекту не до кінця враховують поняття фізичної сили, енергії потужності та фізичної енергії чинників з потоковою випадковою структурою. На цей аспект проблеми динамічної стійкості конструкції за дії чинників із стохастичною структурою звернув увагу Я. П. Драган, ввівши поняття "стохастичного процесу скінченої енергії" і "скінченої потужності потоків (послідовностей) активних фізичних силових дій". За певних умов комплексна дія силових чинників призводить до виникнення солітонів, тобто формування піку енергії та потужності у певний момент часу у найслабшому вузлі конструкції, що її руйнує. Якщо проектант, через свої когнітивні здібності і рівень знань, не враховує енергетичну сутність чинників як руйнівних сил, тоді це призводить до руйнування інфраструктурних об'єктів (міст у Генуї (Італія 2018 р.)), збудований у 1967 р., Китай 2019 р.), руйнівних повеней, пожарів, транспортних катастроф, цунамі. Щодо мостів з металоконструкцій у США (Нью-Йорк), побудованих з урахуванням методів вібраційних розрахунків С. Тимошенко, то вони експлуатуються понад 100 років, за відповідного технічного обслуговування. Оцінка вібраційної стійкості просторових конструкцій, як наявних, так і нових проектів, залишається складною проблемою створення систем контролю і діагностики, не вирішеною повною мірою, і тому розроблення інтегрованих інтелектуальних методів проектування систем контролю методом дистанційного лазерного зондування $\epsilon$ актуальною. Інтенсивний розвиток як соціальної, так і техногенної інфраструктури призводить, внаслідок дії транспортних потоків, електростанцій, виробництв з шкідливими викидами, до росту силового екологічного навантаження на просторові конструкції, корозію металевих складників, росту вібраційних впливів на елементи об'єктів. Подальший розвиток таких негативних процесів призводить до зменшення міцності конструкцій, їхньої стійкості, експлуатаційної надійності та руйнування. Зниження якості несучих конструкцій, через невраховані негативні впливи, унеможливлює прогноз моменту настання аварійних ситуацій. Відповідно, розроблення методів дистанційного контролю вібрацій просторових елементів несучих конструкцій є для різних галузей актуальною проблемою.

Ключові слова: конструкція; вібрація; лазер; сигнал; динамічні процеси; активні чинники; дані; система; інформація; проект; ризики; аварія.

Вступ. На сучасному етапі питання розвитку інформаційно-вимірювальних систем для контролю вібрації складних конструкцій за дії комплексу енергоактивних чинників безконтактним дистанційним методом повною

мірою не розглянуто. Тому розроблення лазерних методів дистанційного контролю динамічних режимів великих просторових конструкцій, за дії активних динамічних у часі й у просторі чинників $є$ важливою проблемою.

Інформація про авторів:

Сікора Любомир Степанович, д-р техн. наук, професор, кафедра автоматизованих систем управління. Email: Issikora@gmail.com; https://orcid.org/0000-0002-7446-1980

Лиса Наталія Корнеліївна, д-р техн. наук, ст. викладач, к-ра інформаційних систем та технологій. Email: Iysa.nataly@gmail.com

Сабат Володимир Іванович, канд. техн. наук, доцент, к-ра інформаційних мультимедійних технологій. Email: v_sabat@ukr.net

Федина Богдана Іванівна, канд. техн. наук, доцент кафедри автоматизації та комп'ютерних технологій. Email: fedynabogdana@gmail.com; https://orcid.org/0000-0001-9487-2851

Кунченко-Харченко Валентина Іванівна, д-р техн. наук, професор, завідувач кафедри інформатики, інформаційної безпеки та документознавства. Email: itib@chdtu.edu.ua

Цитування за ДСтУ: Сікора Л. С., Лиса Н. К., Сабат В. І., Федина Б. І., Кунченко-Харченко В. І. Лазерні та інформаційні технології контролю динамічних зміщень просторових структур об'єктів за дії активних техногенних і природних чинників ризику аварій. Науковий вісник НЛТУ України. 2019, т. 29, № 6. С. 128-135.

Citation APA: Sikora, L. S., Lysa, N. K., Sabat, V. I., Fedyna, B. I., \& Kunchenko-Kharchenko, V. I. (2019). Laser and information technologies for controlling dynamic displacements of spatial structures of objects under the influence of active technogenic and natural risk factors for accidents. Scientific Bulletin of UNFU, 29(6), 128-135. https://doi.org/10.15421/40290625

128 Науковий вісник НЛтУ України, 2019, т. 29, № $6 \quad$ Scientific Bulletin of UNFU, 2019, vol. 29, no 6 
Аналіз літературних джерел. Проблема контролю $\mathrm{i}$ оцінки стійкості просторових конструкцій актуальна впродовж останніх століть (1700-2019) Вона охоплює проблеми руйнування будівель, транспортних засобів, комунікацій, великих мостів, висотних будинків (Тіmochenko, 1967; Roitman, 1990; Makarov \& Kochetkov, 1987) під впливом різних чинників (Marshal, 1989; Draizdel, 1990), вібрації (Kheili \& Kumamoto, 1984; Timoshenko, 1967, 1955; Tikhonov, 1970), зсув грунтів і землетруси (Augusti, Baratta \& Casciata, 1984), старіння компонент і матеріалів (Didenko, 1984; Bobrykin, 1985; Volik, 1985; Tivilov, 1988; Makarov \& Kochetkov, 1987) динамічних транспортних навантажень і потоків (Lbov, 1981; Ragulskie, 1987; Poturaev \& Belobrov, 1989). Одними 3 найменш досліджених $є$ чинники когнітивних i знаннєвих недоліків і помилок, які виникають у процесі проектування (Chikrii, 1992; Krapivin, 1972; Druzhinin \& Kontorov, 1982; Pavlov, 1982; Pospelov, 1986; Roberts \& Geiman, 1986) та подальшої експлуатації з участю оперативного персоналу та проектантів (Smoliakov, 1986; Perkhach \& Podolchak, 2014; Kunchenko-Kharchenko, 2015; Timochenko, 1967; Roitman, 1990).

Тому розроблення методів і засобів, як знаннєвого контролю проектів, так і систем контролю вібрації складних просторових споруд, є надалі актуальною (Sviridov, 1978; Barsegian, 2009), оскільки потребує інтегрованого підходу 3 використанням теорії сигналів (Drahan, Sikora \& Yavorskyi, 2014; Drahan, 1997), теopiï оброблення даних (60. Longren \& Skott, 1981; 61. Impuls, 1975; Barsegian, 2009; Durniak et al., 2011; Kheis, 1981), інтерпретації даних та ситуацій і прийняття рішень (OKonor \& Makdermat, 2018; Printcipy, 1972; Durniak et al., 2011; Kheis, 1981; Tkachuk \& Sikora, 2010; Sikora, Medykovskyi \& Hrytsyk, 2002; Medykovskyi \& Sikora, 2002).

Відповідно, важливою задачею $є$ побудова моделей об'єктів та імітаційне моделювання на аналогах (Roberts \& Geiman, 1986; Skurikhin et al., 1990; Akoff \& Emeri, 1974), що забезпечує виявлення нових фізичних ефектів (Ragulskie, 1987; Bibikov, 1991; Filippov, 1990). Без урахування особливостей когнітивного мислення проектантів неможливі надійні проекти споруд і їх реалізація з відповідним терміном експлуатації та стійкості від руйнування (Ragulskie, 1987; Bibikov, 1991; Filippov, 1990).

Мета дослідження. Для контролю вібрації просторових конструкцій та агрегованих виробничих систем створити й обгрунтувати використання методу лазерного зондування, розробити структурну схему лазерного віброметра (Druzhinin \& Sergeeva, 1990; Gladun, 1987; Pospelov, 1989).

Для розв'язання задачі дистанційного контролю вібрації просторових конструкцій великих розмірів та агрегованих систем поліграфічного виробництва необхідно вирішити такі основні завдання:

1. Обгрунтувати структурні моделі об'єктів і моделі поведінки в часі за дії активних чинників;

2. Обгрунтувати вибір методу лазерного дистанційного зондування для контролю вібрацій конструкцій у критичних місцях об'єкта дослідження та просторову структуру конструкцій об'єкта та (фундамент) платформу агрегованих ліній виробництв високоякісної продукції;

3. Розробити інформаційну технологію опрацювання лазерних сигналів та їх оцінку для визначення вібраційних параметрів.
Методи дослідження. Для розв'язання комплексної науково-прикладної проблеми створення систем дистанційного контролю вібраційного навантаження просторових конструкцій і граничних режимів на підставі лазерного зондування використано методи і теорії: системний аналіз, теорія вібраційних коливань і теорія стохастичних сигналів, основи фізики солітонів, інформаційні технології опрацювання даних, когнітивна психологія підготовки і прийняття рішень, моделювання динамічних систем, методи лазерного зондування просторових динамічних зміщень, факторний аналіз, теорія конфліктів і ризиків аварій.

Моделі динамічних чинників, які впливають на просторову структуру. Оскільки динамічні чинники (Timoschenko, 1955; Tivilov, 1988; Karzov, Margolin \& Shvetcova, 1993) мають енергоактивну структуру (Timoshenko, 1967), тоді неврахування їх сутності призводить до розвалу механічної просторової структури внаслідок коливань і солітонних ефектів (Durniak et al., 2013b).

Відповідно, дослідження їх динаміки потребує використання та створення нових методів і систем контролю на підставі лазерного дистанційного зондування, що забезпечило б виявлення коливань просторової структури конструкцій (Sikora, 1988; Mesarovich, Mako \& Takakhara, 1973). Для розв'язання зазначених вище проблемних задач необхідно створити:

1. Модель $n$-мірного просторового коливання для довгої ділянки моста (100 м) та спільного фундаменту для агрегованого поліграфічного виробництва.

2. Модель енергетичного солітону для зустрічних потоків транспорту, як збурювальних чинників $\left(\stackrel{\vec{n}^{2}}{\longrightarrow} \uparrow \vec{n}_{n}\right)$ по вертикалі і повздовж відносно опор.

3. Модель вітрового навантаження зі змінною швидкістю, як чинник збурення поперечних коливань.

4. Транспортні потоки, як збуджувальні чинники 3 неперервною та дискретною структурою (однорідні, неоднорідні, групові (односторонні, зустрічні)):

$$
T \Pi_{1}^{d}=\left\{\left(m_{i}, V_{i}\right)\right\}_{T n}, T \Pi_{2}^{\mathrm{d}}=\left\{\sum_{i=1}^{K}\left(m_{j}, V_{j}\right)_{t i}\left(t_{i} \in T_{n}\right)\right\},
$$

при цьому маємо $\sum_{i=1}^{n} m_{i} \leq M_{d}$, де: $T \Pi_{\mathrm{i}}-$ транспортний потік; $m_{i}$ - маса транспортної одиниці руху; $V_{i}$ - швидкість руху; $T_{n}-$ груповий час; $M_{d}$ - максимальне масове навантаження.

5. Модель дії транспортних потоків на фундаменти i платформи із встановленими агрегатними лініями виробництва високоякісної поліграфічної багатоколірної продукції (рис. 1).

6. Метод лазерного зондування просторової структури об'єкта дослідження, який є підставою для розроблення інформаційно-вимірювальних систем (рис. 2).

Активні чинники впливу на динамічну та структурну стійкість просторово-розподілених об'єктів. Згідно з проведеними дослідженнями (Napartovich, 1991; Hryhoruk, Korotkov \& Khyzhyiak, 1994), виділимо системні активні чинники дії.

Відсутність систем ефективного контролю структури і надійності конструкцій об'єкта, динаміки руйнування за рахунок деформаційних зміщень під впливом активних чинників - автомобільних і транспортних потоків та природних динамічних чинників (Batrakov, Butusov, \& Grechka, 1981; Isimaru, 1981): 
1. Конфлікти та неповнота знань, які призводять до помилок на етапі проектування просторової конструкції:

- неповнота даних про об'єкт, структури, матеріали, динаміку, чинники, навантаження, руйнівні чинники, навантаження, руйнівні сили;

- розриви у системі знань проектантів, що спричиняє системні та структурні помилки.

2. Конфлікти, які виникають у процесі експлуатації за неповноти даних і знань персоналу:

- структура динамічних навантажень i їх зміни на довгих i коротких інтервалах часу;

- сезонні, природні чинники, катаклізми, які призводять до пошкодження конструкцій.

3. Транспортні потоки, як збудники коливань просторових конструкцій мостів, платформ:

- зміна рівня надійності та старіння металу та бетону опор, платформ внаслідок вібраційних коливань;

- динамічне руйнування матеріалів, неадекватність структури проекту і об'єкта до вимог і тенденцій зміни трафіка і його масових параметрів та надійності.

4. Неврахування активних чинників на коливання грунтів платформ і опор, деформація від динамічного збурення і гравітаційних деформацій.
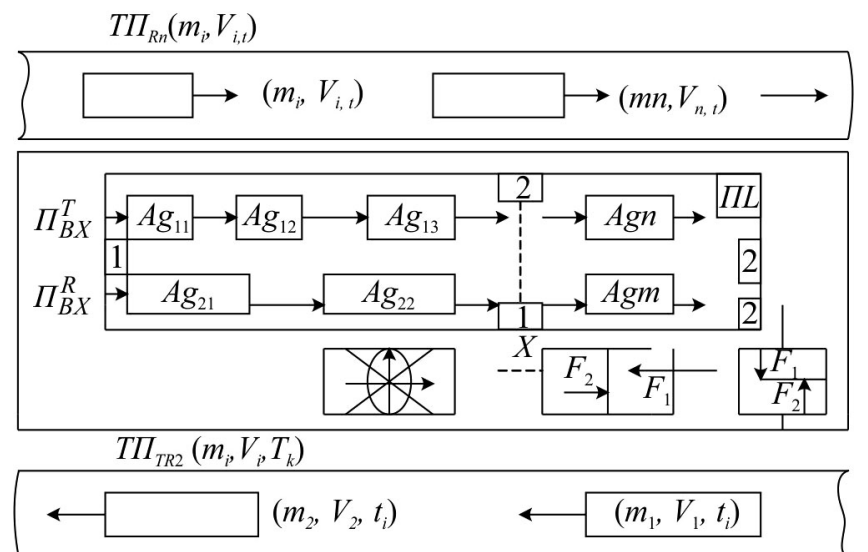

Рис. 1. Модель структурної дії чинників впливу на агреговану структуру зі спільною платформою: $\Pi B_{B X}^{T}-$ вхідний потік ресурсів; $\Pi_{B X}^{R}-$ вихідний потік ресурсів за інтервал часу $T$; $\left\{A g_{i}\right\}$ - агрегатна структура на спільній платформі $(\Pi L) ;[1]$, [2] - координати встановлення лазерної системи для різних варіантів зондування

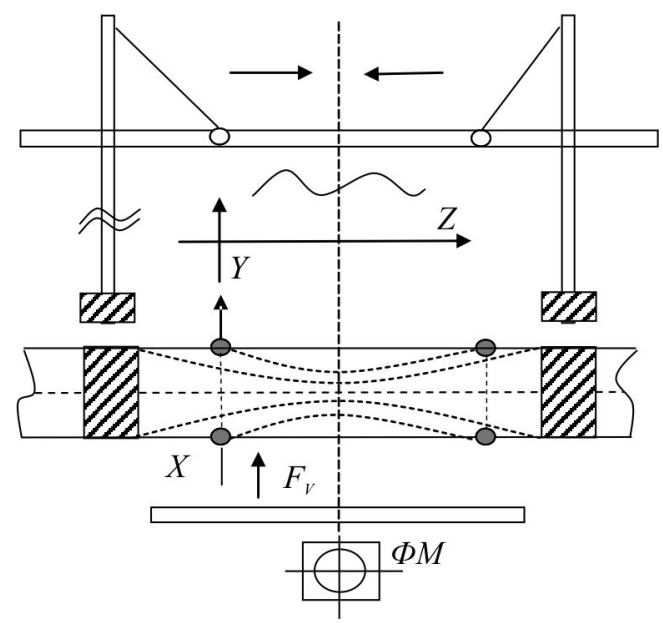

Рис. 2. Метод лазерного зондування просторової структури

Відбір і опрацювання різнорідних даних про стан і динаміку просторових об'єктів 3 вібрацією (Kovalenko, 1980; Kogan, 1986; Borntcev, 1985). На сучасному етапі розвитку науки і техніки необхідно більше уваги приділяти фундаментальним дослідженням, теоретичному узагальненню відомих фактів i виявленню завдяки цьому нових, які стають основою формування бази знань (Lbov, 1981; Poturaev \& Belobrov, 1989; Gusev, 1989). Одним із шляхів отримання нової інформації в умовах стохастичних збурень $є$ синтез робастних алгоритмів опрацювання даних і створення на їх підставі інформаційно-вимірювальних систем для контролю вібрації з використанням лазерного дистанційного зондування областей найбільших напружень і зміщень просторових конструкцій (Smoliakov, 1986; Perkhach \& Podolchak, 2014).

Залежно від типу конструкції, рівень вібрації (відбір даних) оцінюється методом зондування по відбитому променю (дзеркальна поверхня на конструкції), або прямим проекційним зондуванням (фотоматриця встановлена у місці контролю конструкціі) (рис. 3).

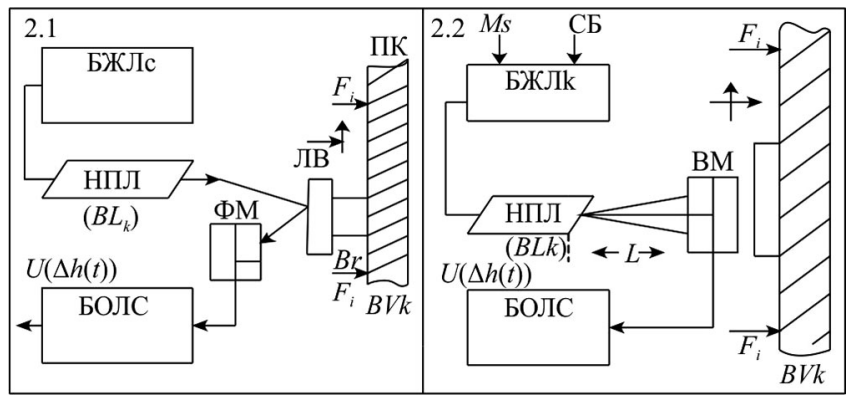

Рис. 3. Схеми дистанційного зондування області вібрації конструкції (2.1. - по відбитому променю; 2.2. - проекційне пряме зондування): НПЛ - напівпровідниковий проекційний лазер; БЖЛс - блок живлення стаціонарний; БЖЛк - блок живлення лазера комплексний (мережа або сонячна батарея); ФМ фотоматриця з базисом ВМ; ЛВ - лазерний відбивач з базисом $\mathrm{Br}$; БОЛС - блок оброблення лазерного сигналу; $U(\Delta h(t))$ сигнал вібрації конструкції

Розглянемо схему вібраційних перетворень лазерного сигналу при зондуванні просторової конструкції (рис. 4).

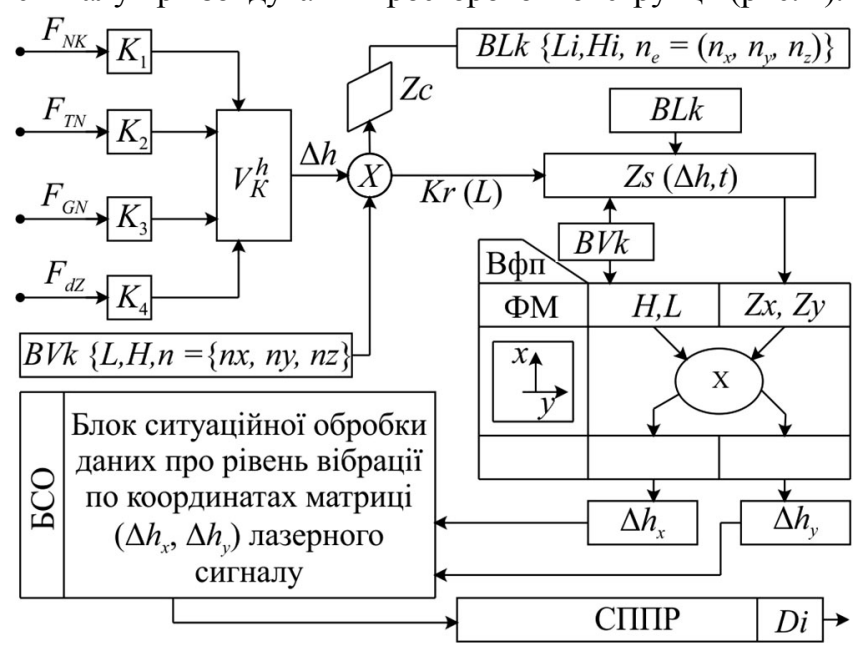

Рис. 4. Структурна схема перетворень лазерного сигналу за динамічних зміщень області зондування просторової конструкції: $F_{N \mathrm{~K}}$ - чинник динамічного напруження конструкцій; $F_{T N}-$ чинник динамічного транспортного напруження; $F_{G N}-$ чинник гравітаційного напруження просторової конструкції; $F_{d Z}-$ чинник динамічних зміщень природних сезонних змін (температура, вологість, вітрове навантаження); $V_{K}^{h}$ - область контролю зміщення елемента конструкції; $B V k$ - базис геометричної області контролю; $B L k$ - базис установки лазера; $Z c-$ зондуючий сигнал; $Z s$ - збитий сигнал; $\operatorname{Kr}(L)$ - коефіцієнт розсіяння лазерного променя 
Інформаційні перетворення сигналів лазера у процесі вимірювання динамічних зміщень елементів конструкції можна подати у такому вигляді:

1. $\left.\left\{\sum_{i=1}^{u} K_{i} F_{i}\right\} \stackrel{(t, \tau)}{\longrightarrow}\left\{V_{k}^{n}\right\} \stackrel{\operatorname{Ar}(t, \tau)}{\longrightarrow} \Delta h(t, \tau)\right|_{\text {вVk }}$ - модель процесу формування зміщення області контролю конструкції за рахунок оператора впливу чинників $A_{i}=(t, \tau)$ у момент часу $t$ на інтервалі $\tau$,

$$
\text { 2. } \begin{gathered}
\left.\left.Z_{C}\left(P, d, F_{S}(\tau), t\right)\right|_{B L k} \stackrel{A z, \Delta}{\longrightarrow} Z_{S}\left(P_{S}, d_{S}, F_{S} \mid \Delta h, t\right)\right|_{B_{\Phi \Pi}} \rightarrow- \\
\rightarrow A(\Delta h \rightarrow \Delta \mathrm{U}) \otimes Z_{S}(\Delta h) \rightarrow\left(\Delta h_{x}, \Delta h_{y}\right),
\end{gathered}
$$

модель перетворення параметрів лазерного сигналу в області $\left(V_{\kappa}^{\mathrm{n}}\right)$ зондування зміщення елементів конструкції під впливом динамічних чинників $\left(P_{S}-\right.$ потужність лазерного сигналу, $d$ - діаметр пучка, $F_{S}$ - форма сигналу).

$$
\begin{gathered}
Z_{S}\left(\Delta h, P_{S}, t, F_{S}(\tau)\right) \stackrel{V_{k}^{n}}{\longrightarrow} \underset{\downarrow}{\otimes} \stackrel{A_{\phi M}}{\longleftarrow} K_{M}(\Delta h \rightarrow \Delta \mathrm{U}) \mid B_{\phi M} \\
\Pi D\left(\Delta h_{X}, \Delta h_{y} \mid t, T_{K}\right) \leftarrow A \lg (\Delta U(h) \rightarrow \Delta \hat{h}) .
\end{gathered}
$$

Модель вимірювальних даних, отриманих у процесі лазерного зондування області $V_{K}$, сформованих на виході фотоматриці у вигляді потоку даних ПD()на підставі алгоритму.

На підставі запропонованих моделей вимірювальних перетворень синтезується інформаційно-контрольна система вібраційних вимірювань.

Стохастичні методи синтезу IКС в основному застосовують гаусовські моделі зміни параметрів об'єкта та зондуючого сигналу, причому мало уваги приділяється розв'язанню проблеми забезпечення робастності систем і стійкості алгоритмів та процедур опрацювання результатів спостереження. Основні дослідження при цьому проводять за такими напрямками статистики i теорії систем (Volik, 1985), які грунтуються на (Drahan, Sikora \& Yavorskyi, 2014; Timoshenko, 1967, 1955):

- ймовірних моделях випадкових процесів і полів для опису вібрації об'єкта та чинників впливу;

- процедурах виявлення, розпізнавання, оцінки параметрів i фільтрація сигналів виходячи 3 вибраних моделей динаміки, які відображають стан технічної системи або просторового об'єкта в поточному часі;

- алгоритмах просторово-часового оброблення сигналів із врахуванням стохастичної структури каналів розповсюдження і моделей збурень для оцінки траєкторій і трендів у реальному часі зміни динамічних параметрів;

- процедурах багатокритеріальної оптимізації процесу прийняття рішень на управління в умовах нечіткості даних, яке змінює режим навантаження;

- процедурах динамічної оцінки ситуації в енергоактивних об'єктах;

- алгоритмах розпізнавання образів (просторово-часових, ситуаційних), сформованих з потоків даних у різних режимах функціонування об'єкта;

- процедурах аналізу і синтезу IBC для оцінки стану просторових конструкцій технологічних об'єктів з різним ступенем керованості;

- виборі індикаторів ознак граничних і аварійних режимів поточної динамічної ситуації в конструкціях відносно цільової області допустимих параметрів.

Класичний підхід до структурного синтезу IKC полягає в тому, що розроблення структури проводиться на основі технічного завдання в рамках наявних методик аналізу і синтезу, виходячи зі заданої моделі вимірювальної системи без урахування цільової орієнтації.
При цьому, не завжди повною мірою, враховується інформація про структуру об'єкта дослідження, умови його функціонування при обмеженнях на ресурси, спостережуваності і надійності. Насамперед при реалізації процедури синтезу IКС потрібно мати на увазі цілі функціонування технологічного об'єкта, що дає змогу побудувати змістовну модель і сформувати кількісні критерії оптимізацї̈ у вигляді системи функціоналів якості.

При стохастичному характері функціонування об'єкта контролю часто доводиться стикатися із ситуацією недостатньої апріорної інформації. Особливо ця складна проблема виникає при спостереженні за станом технологічних просторових структур, з неідентифікованою структурою та функціями, нестабільними в часі i розмитими по пріоритетах локальними цілями, які не мають стратегічних напрямків, а процедури прийняття рішень не мають системного й ефективного технологічного забезпечення. У цих випадках для прийняття рішень використовується принцип дуального управління процесом експлуатації, який передбачає одночасне використання сигналів як засіб вивчення технологічного об'єкта, траєкторії поведінки під дією збурювальних чинників. Але існують умови, за якими оптимальне спостереження і управління стає неможливим. Ця ситуація виникає при ресурсних обмеженнях або динамічних збуреннях, що значно перевищують рівень інформативного корисного сигналу. Це приводить до дезорієнтації ЛІКС і прийняття некоректних рішень, а в граничних режимах - до аварійної ситуації. У цих умовах втрачається робастність і працездатність IКС, побудованих на базі класичної теорії фільтрації і теорії автоматичних систем із зворотним зв'язком з використанням ієрархічних структур Масаровича. Проблеми синтезу ЛІКС систем, а також інформаційні аспекти функціонування IKC, як формувача образу динамічної ситуації в каналі контролю системи управління, в літературі практично не розглядають, що робить актуальною проблему синтезу робастних систем спостереження динамічного стану ЛІКС. Це потребує пошуку принципово нових підходів до синтезу ЛІКС, із врахуванням здобутків програмно-цільового та ситуаційного аналізу, що дає змогу адекватно відобразити ситуацію в цільовому просторі системи СППР, а аналіз інформації про зміну можливих ситуацій покладено в основу процедури формування стратегій прийняття антикризових рішень, на підставі інтерпретації поведінки траєкторії руху конструкцій під впливом активних динамічних чинників у просторі і часі.

Лазерне зондування коливань просторової структури моста 3 довгим прольотом. Для виявлення та ідентифікації просторових коливань об'єктів транспортної інфраструктури та великих будівельних конструкцій, розроблено метод проекційного лазерного зондування зміни траєкторії елементів у певних кризових точках конструкцій. Згідно з (Timoschenko, 1955), просторові зміщення координат опорних конструкцій можна подати у вигляді траєкторій (рис. 5).

Для приймання просторового потоку лазерних сигналів матриця (ФM) фотоприймача повинна мати 4квадратну структуру для оцінки динаміки зміщень контрольних точок по векторах $\left(\vec{n}_{X}, \vec{n}_{Y}, \vec{n}^{+}, \vec{n}^{-}\right)$згідно 3 різницевим рівнянням (Karzov, Margolin \& Shvetcova, 1993)

$$
\text { trak } \Delta U_{\text {var }}^{t}\left(\vec{n}_{X} \Delta x\right)=K_{M}\left(U_{x t}^{+}-U_{x t}^{-}\right)=K_{M} K_{Y S}\left(P_{S i}^{+}-P_{S i}\right)^{t},
$$


де: $P_{S i}^{+}, P_{S i}^{-}-$потужність прийнятого променя лазера $\Delta U_{\text {var }}\left(\vec{n}_{X} \Delta x\right) ; K_{M}, K_{Y S}-$ коефіцієнти перетворення матриці і розсіяння променя; $P_{S i}^{+}, P_{\overline{S i}}^{-}$варіація напруги на виході каналу вимірювань коливань контрольної точки по вектору $\left(\vec{n}_{X i}\right)$.

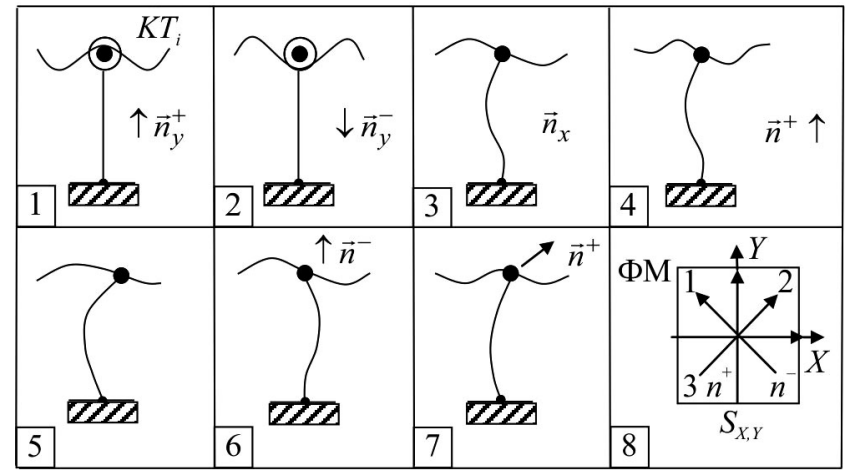

Рис. 5. Просторова орієнтація векторів активних впливів на площині $\mathrm{S}_{\mathrm{X}, \mathrm{Y}}$ на опори моста 3 довжиною полотна прольоту від 20 до 100 м і більше
На рис. 6 наведено схему можливих коливань платформи моста та відбір даних лазерним зондуванням областей контролю зміщення.

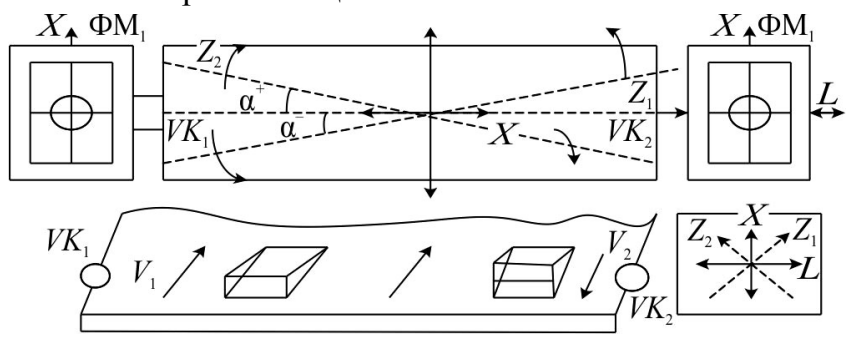

Рис. 6. Коливання полотна моста при зустрічних транспортних потоках зі швидкістю $V(t)$ та грунтових зміщеннях опор фундаментів та платформ

Відповідно до рис. 4 і 5 та моделей інформаційних перетворень формується структурно-інформаційна схема методу проекційного лазерного зондування коливань контрольної точки конструкції (рис. 7) (Tivilov, 1988; Karzov, Margolin \& Shvetcova, 1993).

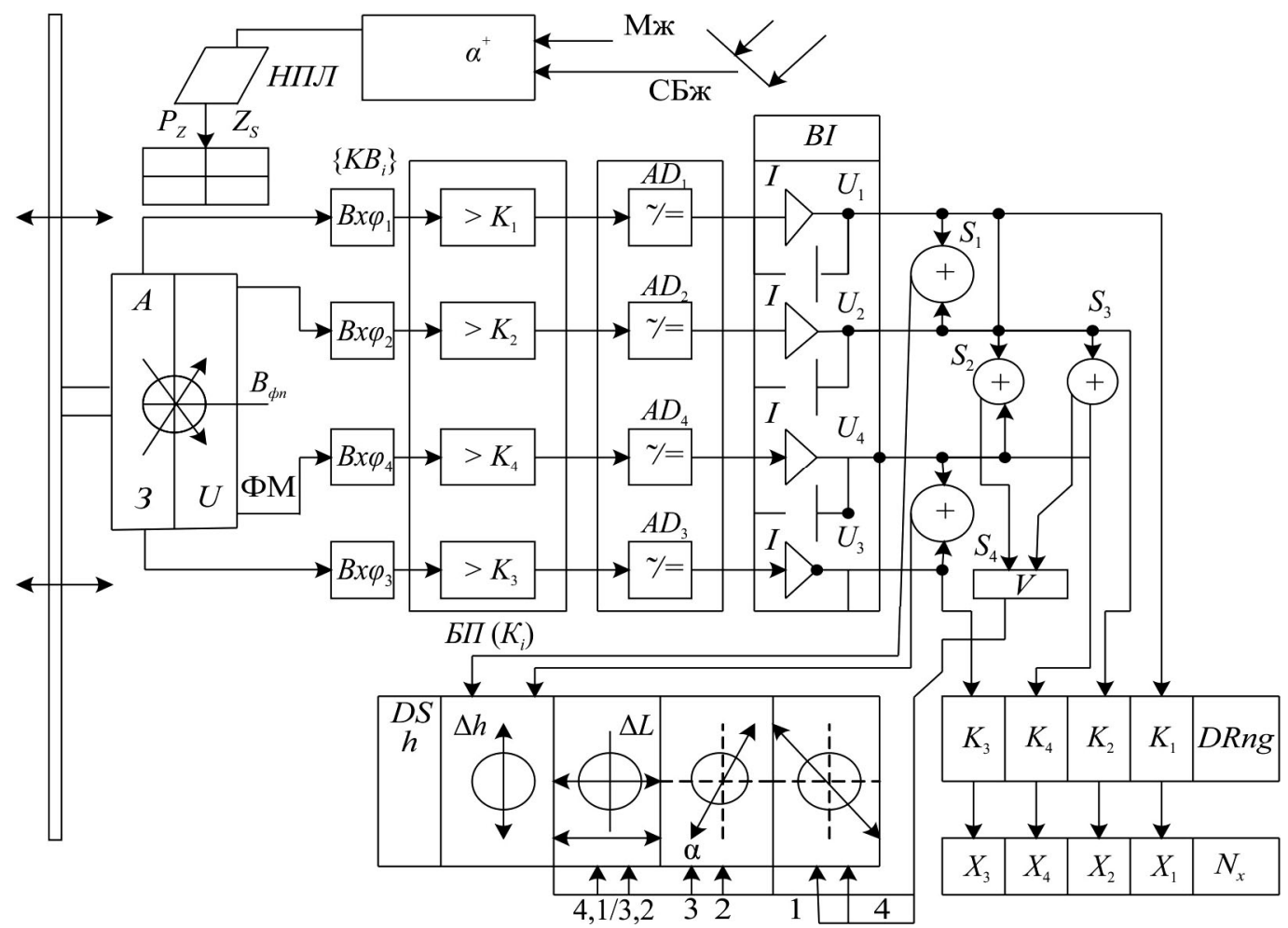

Рис. 7. Лазерний просторовий віброметр з фіксацією викидів (рідкі подіі): ФМ - 4-квадратна матриця фотоприймача; $P_{Z}-$ потужність зондуючого лазера; $P_{S}-$ прийнятий сигнал; $\left\{k B_{i}\right\}$ - канали контролю динаміки коливань у базисі $\{x, y, n\}$ із вхідними фільтрами сигналів $\left\{B_{X} \Phi_{i}\left(f_{M}, \Delta f\right)\right\}$ з частотою $f_{M}$ та слугою пропускання $\Delta f ;\left\{Б П\left(K_{i}\right)\right\}$ - блок підсилювачів сигналу з коефіцієнтом $K_{i} ; A D_{i}$ - аналогові детектори сигналу; $B I\left(U_{S}\right)$ - блок інтеграторів сигналу; $\left\{S_{i}\right\}$ - операційні суматори сигналів; $D R n g$ - дискретний ранговий класифікатор навантаження конструкції; $N_{X}$ - цифровий індикатор; $D S_{n}-$ дисплейний комплексний індикатор динамічних зміщень по осях $\left(X, Y, Z^{+}, Z^{-}\right)$; Мж- система мережевого живлення; СБж - сонячні батареї.

Експериментальні дослідження. Оскільки для дослідження вібрації мостів, фундаментів, платформ, потрібні спеціальні дозволи і апаратура, було використано аналоги для оцінки просторових хвиль під дією чинників збурень, з використанням високотемпературних гідродинамічних потоків в'язкої рідини $\left(T^{\circ} C=[900-1100)\right.$, на підставі моделі динамічного балансу (завантаження - розхід) ресурсів у різних режимах управління (скловарна піч- 3 боковим відбором розплавленого скла) і лазерним зондуванням зміщення рівня.
Експерименти з оцінки збурення поверхні скломаси методом лазерного зондування проводили на печі (рис. 8) Рокитнівського склозаводу за період (2010-2011 pp.) та інших печах за період (1990-2015 pp). На рис. 8 (1.0) наведено схему скловарної печі (СП), де $\left\{3 B_{1}\right\}-$ завантажувачі (неперервні або імпульсні) шихти; $\left\{\Pi B_{i}\right\}$ - пристрої відбору скломаси; $V_{S}$ - область лазерного контролю; ПДЗ - просторові динамічні збурення об'єму і поверхні розплавленої скломаси породжені чинниками збурення $\left\{F_{i}\right\}$. Солітонні ефекти виникають 
у зоні контролю, коли пряма хвиля збурення поверхні у каналі відбору маси трапляється з відбитою.

Наведемо графіки траєкторії зміщення поверхні в області зондування та модель формування динамічного солітону у каналі відбору маси. На графіках відображено зміни режимів функціонування об'єкта за різних режимів навантаження (дискретний штовхальний механізм). При виконанні управляючих команд на завантажувальний механізм неоднорідні потоки шихти потрапляють на поверхню скломаси і збуджують повздовжні хвилі. Повздовжні хвилі розповсюджуються по розплавленій в'язкій поверхні, проходять вздовж печі у канал відбору маси, де за певних умов формуються солітони динамічного зміщення поверхні.
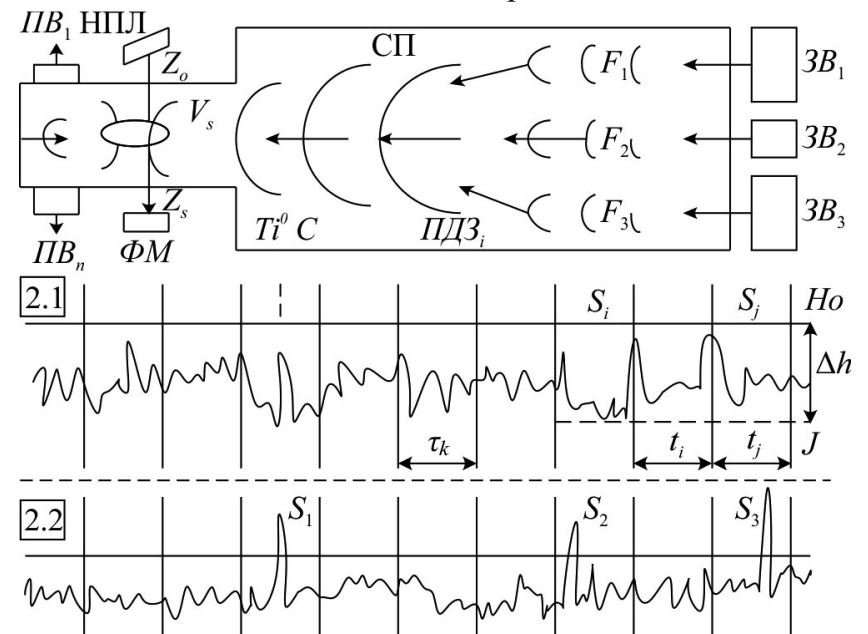

Рис. 8. Гідродинамічна модель формування поверхневих солітонів: (зверху) - структура скловарної печі, як моделі, де $C П-$ скловарна піч у контурному зображені; $\left\{3 B_{1}\right\}$ - завантажувачі шихти, як збурю вальні чинники; $V_{S}$ - швидкість і час завантаження $\left(V_{3 \mathrm{i}}, \tau_{3 i}\right) ;\left\{\Pi B_{i}\right\}$ - потік відбору продукції; $\left\{T_{i}^{0} C\right\}$ - теплове поле поверхні $\left(T_{i}^{0} C-980^{\circ} C\right)$; НПЛ - напівпровідниковий проекційний лазер для зондування поверхні; ФМ - фотоматриця прийому лазерного сигналу $Z_{S}$, відбитого від області контролю $V_{S} ;\left\{F_{i}\right\}$ - чинники, які збурюють поверхневі хвилі при динамічному завантажені ресурсу $F_{i}=\left\{m_{i}, \tau_{i 3}\right\}$ - масою $m_{i}$, протягом інтервалу часу $\tau_{i 3}$

2.1. Графік запису траєкторії коливань поверхні в'язкої маси в області зондування $V_{S}$, характеризується параметрами: $\left(\tau_{K}=60 \mathrm{c}\right)$ інтервал часу контролю, $\Delta \tau_{i j}-$ відстань між солітонами, $\Delta h_{i}$ - амплітуда викидів, $\Delta_{n}-$ ранг шкали амплітуди імпульсів при $\left\{N s=0,5 \mathrm{MM}, A_{n}=\right.$ 0,005 мм . Для: 2.1. - амплітуда солітонів: $S_{i}=0,3$ мм, $S_{j}=0,2$ мм; 2.2. - амплітуда солітонів $S_{1}=0,2 \mathrm{мм}, S_{2}=$ 0,25 мм, $S_{3}=0,3$ мм.

На рис. 9 наведено схему формування солітонів.

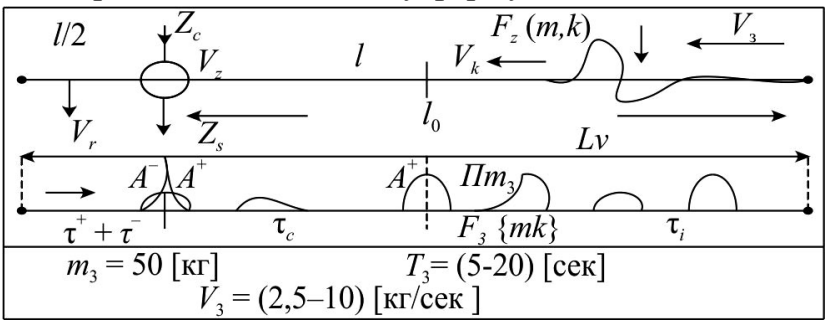

Рис. 9. Модель формування солітонного імпульсу при завантажені ресурсу на вхід ванни: $V_{Z}$ - область зондування; $Z_{C}-$ зондуючий сигнал; $Z_{S}$ - відбитий сигнал; $L_{V}-$ довжина ванни; $L_{O}$ - віддаль до області контролю; $V_{K}$ - швидкість потоку завантаження; $V_{r}$ - швидкість відбору маси на виході об'єкта; $F_{3}\left(m_{K}\right)$ - чинник збурення при імпульсному завантажені ресурсу; $V_{3}$ - швидкість потоку завантаження; $\tau_{e}$ - довжини хвильового імпульсу при збурені поверхні: $1 . \mathrm{L}_{0}=16 \mathrm{M}, 2$. $L_{V}=20 \mathrm{M}, 3 . U=l=4 \mathrm{M}$

Умова збурення солітону на поверхні в області контролю: "Якщо на віддалі $(l / 2)$ до $\left(V_{Z}\right)$ збурено поверхню імпульсом 3 амплітудою $A_{1}^{t}$ в момент $t_{1}$, який проходить до точки $l_{k}$ в момент $t_{1}$ появився імпульс $A_{2}^{+}$, то при зустрічі в момент $t_{2},\left(\tau=t_{2}-t_{1}\right)$ формується солітон з амплітудою $A_{s l}=\left(A_{1}^{+}+A_{2}^{+}\right)$(рис. 10).

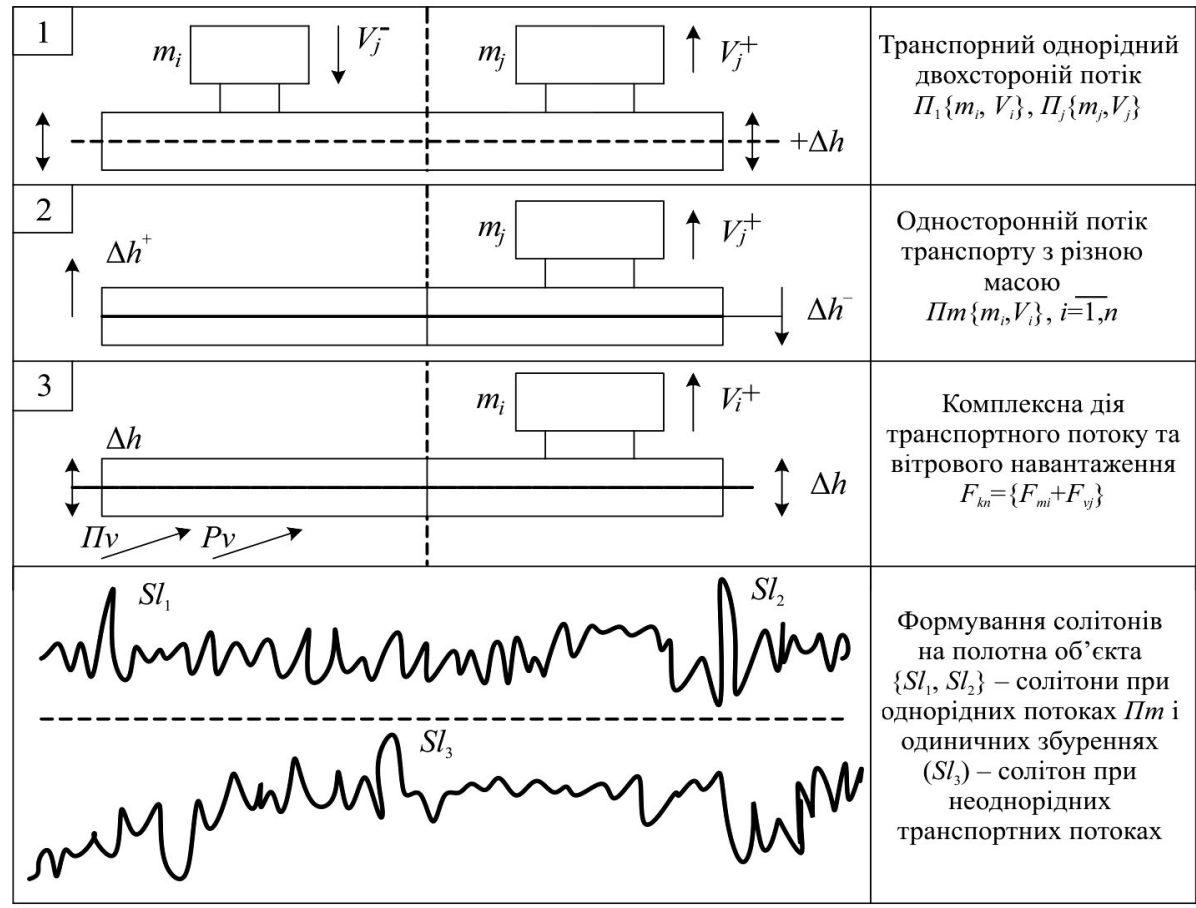

Рис. 10. Моделі динамічних навантажень на полотно моста 
Для пошуку необхідної стратегії управління $T S$ - необхідно "при дії збурень" провести імітаційну гру на моделі $\langle C U S \leftrightarrow T S\rangle$ для різних класів збурень, визначити на основі розбиття інтервалу $I_{Z T S}$ стійкі ляпуновські області у фазовому просторі, а за ними - параметри стратегії управління надійністю просторових конструкцій.

Наукова новизна. На підставі системного аналізу та когнітивних концепцій розглянуто кризові ситуації, які виникають у техногенних системах з енергоактивними чинниками впливу. Обгрунтовано положення, що тільки за умов врахування цих чинників на всіх етапах - від проектування до побудови та експлуатації можна забезпечити високий рівень безаварійного функціонування техногенних регіональних і глобальних структур. Отже, для того щоб забезпечити високий рівень надійності техногенних систем, потрібно у процесі проектування враховувати активні, інформаційні та когнітивні чинники впливу на розроблення проекту та його виконання з урахуванням розвитку реальних динамічних ситуацій.

Висновок. Для того, щоб забезпечити високий piвень надійності техногенних систем, необхідно у процесі проектування враховувати активні, інформаційні та когнітивні чинники впливу на розроблення проекту та його виконання з урахуванням розвитку реальних динамічних ситуацій. Як показують останні дані про руйнацію просторових структур мостів (гідроспоруд, дамб, водосховищ), проектанти не врахували всі активні чинники, які діють на ці споруди в різні сезони. У разі зростання активності цих чинників виникають пожежі, повені, руйнуються секції мостів 3 великою довжиною (довжина понад 100 м), що свідчить про те, що в процесі проектування не було проведено експертизи проекції інженерами- інтеграторами і не враховано енергетичні i фізичні аспекти дії чинників на мікроструктуру об'єктів.

\section{Перелік використаних джерел}

Akoff, R., \& Emeri, F. (1974). O tceleustremlennykh sistemakh. Moscow: Sov. radio, 272 p. [In Russian].

Augusti, G., Baratta, A., \& Casciata, F. (1984). Probabilistic Methots in Structural Engineering. London, 584 p.

Barsegian, A. A. (2009). Analiz dannykh i protcessov. St. Petersburg, 512 p. [In Russian].

Batrakov, A. S., Butusov, M. M., \& Grechka, G. P. (1981). Lazernye izmeritelnye sistemy. Moscow: Radio and communication, $456 \mathrm{p}$. [In Russian].

Bibikov, Iu. N. (1991). Mnogochastotnye nelineinye kolebaniia i ikh bifurkatcii. Leningrad: LSU, 141 p. [In Russian].

Bobrykin, N. A. (Ed.). (1985). Agregatnye kompleksy tekhnicheskikh sredstv ASU-TP. Leningrad, 271 p. [In Russian].

Borntcev, G. B. (Ed.). (1985). Metody statisticheskoi obrabotki izobrazhenii i polei. Novosibirsk: NETI, 130 p. [In Russian].

Bychenok, N. N., Gaiduk, O. V., Mostovoi, V. V., Tereshhenko, V. S., \& Senchenko, A. D. (2000). Prognozno-analiticheskaia sistema podderzhki priniatiia reshenii po regionalnoi bezopasnosti. Control systems and machines, 4, 88-95. Kiev. [In Russian].

Chikrii, A. A. (1992). Konfliktno-upravliaemy protcessy. Kiev: Scientific thought, 384 p. [In Russian].

Didenko, K. I. (1984). Proektirovanie agregatnykh kompleksov tekhnicheskikh sredstv ASU-TP. Moscow: Energoatomizdat, 168 p. [In Russian].

Drahan, Ya. P. (1997). Enerhetychna teoriia liniinykh modelei stakhostychnykh syhnaliv. Lviv: TsSD, 361 p. [In Ukrainian].

Drahan, Ya. P., Sikora, L. S., \& Yavorskyi, B. I. (2014). Systemnyi analiz stanu ta obgruntuvannia osnov suchasnoi teorii stokhastychnykh syhnaliv: enerhetychna kontseptsiia; matematychnyi substrat; fizychne tlumachennia. Lviv: SPF "Ukrainian Technologies", 240 p. [In Ukrainian].

Draizdel, D. (1990). Vvedenie v dinamiku pozharov. Moscow: Stroiizdat, 424 p. [In Russian].

Druzhinin, G. V., \& Sergeeva, I. V. (1990). Kachestvo informatcii. Moscow: Radio and communication, 172 p. [In Russian].

Druzhinin, V. V., \& Kontorov, D. S. (1982). Konfliktnaia radiolokatciia. Moscow: Radio and communication, 124 p. [In Russian].

Durniak, B. V., Sikora, L. S., Antonyk, M. S., \& Tkachuk, R. L. (2013a). Kohnityvni modeli formuvannia stratehii operatyvnoho upravlinnia intehrovanymy iierarkhichnymy strukturamy $v$ umovakh ryzykiv i konfliktiv. Lviv: Ukrainian Academy of Printing, 449 p. [In Ukrainian].

Durniak, B. V., Sikora, L. S., Atonyk, M. S., \& Tkachuk, R. L. (2013b). Avtomatyzovani liudyno-mashynni systemy upravlinnia intehrovanymy iierarkhichnymy orhanizatsiinymy ta vyrobnychymy strukturamy $v$ umovakh ryzyku ta konfliktiv. Lviv: Ukrainian Academy of Printing, 514 p. [In Ukrainian].

Durniak, B. V., Sikora, L. S., Hrunyk, A. I., \& Tymchenko, O. V. (2011). Lazernyi kontrol vibratsii ahrehativ transportnoi infrastruktury. Lviv: Ukrainian Academy of Printing, 157 p. [In Ukrainian].

Durniak, B. V., Sikora, L. S., Lysa, N. K., Tkachuk, R. L., \& Yavorskyi, B. I. (2017). Informatsiini ta lazerni tekhnolohii vidboru potokiv danykh ta yikh kohnityvna interpretatsiia $v$ avtomatyzovanykh systemakh upravlinnia. Lviv: Ukrainian Academy of Printing, 644 p. [In Ukrainian].

Filippov, A. T. (1990). Mnogolikii soliton. Moscow: Science, 288 p. [In Russian].

Gladun, V. P. (1987). Planirovanie reshenii. Kiev: Scientific thought, 168 p. [In Russian].

Gusev, A. S. (1989). Soprotivlenie ustalosti i zhivuchest konstruktcii pri sluchainykh nagruzkakh. Moscow: Engineering, 248 p. [In Russian].

Hryhoruk, V. I., Korotkov, P. A., \& Khyzhyiak, A. I. (1994). Lazerna fizyka. Kiev: MP "Lesia", 478 p. [In Ukrainian].

Impuls. (1975). Integralnyi metod izmereniia impulsov. Moscow: Sov. Radio, 280 p. [In Russian].

Isimaru, A. (1981). Rasprostranenie i rasseianie voln v sluchaino neodnorodnykh sredakh. Moscow: World, 279 p. (Vol. 1), 317 p. (Vol. 2). [In Russian].

Karzov, G. P., Margolin, B. Z., \& Shvetcova, V. A. (1993). Fizikomekhanicheskoe modelirovanie protcessov razrusheniia. St. Petersburg: Polytechnic, 391 p. [In Russian].

Kheili, E. Dzh., \& Kumamoto, Kh. (1984). Realiability engineering and risk assessment. Moscow: Engineering, 528 p. [In Russian].

Kheis, D. (1981). Prichinnyi analiz v statisticheskikh issledovaniiakh. Moscow: Finance and Statistics, 255 p. [In Russian].

Kogan, R. I. (1986). Intervalnye otcenki $v$ geologicheskikh issledovaniiakh. Moscow: Nedra, 160 p. [In Russian].

Kovalenko, I. N. (1980). Analiz redkikh sobytii pri otcenke effektivnosti i nadezhnosti sistem. Moscow: Sov. Radio, 208 p. [In Russian].

Krapivin, V. F. (1972). Teoretiko-igrovye metody sinteza slozhnykh sistem $v$ konfliktnykh situatciiakh. Moscow: Sov. radio, 192 p. [In Russian].

Kunchenko-Kharchenko, V. T. (2015). Informatsiino-upravlinske dokumentuvannia $v$ iierarkhichnykh systemakh: Kontseptsii zabezpechennia zakhystu informatsii. Lviv: Ukrainian Academy of Printing, 376 p. [In Ukrainian].

Lbov, G. S. (1981). Metody obrabotki eksperementalnykh dannykh. Moscow: Science: Sibirskoe otdelenie, 157 p. [In Russian].

Longren, K., \& Skott, E. (Eds). (1981). Solitony v deistvii. Moscow: World. [In Russian].

Makarov, B. P., \& Kochetkov, B. E. (1987). Raschet fundamentov sooruzhenii na sluchaino neodnorodnom osnovanii pri polzuchesti. Moscow: Stroiizdat, 256 p. [In Russian].

Marshal, V. (1989). Osnovnye opasnosti khimicheskikh proizvodstv. Moscow: World, $671 \mathrm{p}$. [In Russian].

Medykovskyi, M. D., \& Sikora, L. S. (2002). Avtomatyzatsiia keruvannia enerhoaktyvnymy obiektamy pry obmezhenykh resursakh. Lviv: TsSD, 298 p. [In Ukrainian]. 
Mesarovich, M., Mako, D., \& Takakhara, I. (1973). Teoriia ierarkhicheskikh mnogourovnevykh sistem. Moscow: World, $344 \mathrm{p}$.

Napartovich, A. P. (Ed.). (1991). Spravochnik po lazernoi tekhnike. Moscow: Energoatomizdat, 540 p. [In Russian].

OKonor, D., \& Makdermat, Y. (2018). Systemne myslennia i poshuk neordynarnykh tvorchykh rishen. Kiev: Our format, $240 \mathrm{p}$.

Pavlov, V. V. (1982). Konflikty $v$ tekhnicheskikh sistemakh. Kiev: Higher school, 184 p. [In Russian].

Perkhach, O. L., \& Podolchak, N. Yu. (2014). Korporatyvni konflikty ta metody yikh podolannia. Lviv: Publishing House NU "LP", 192 p. [In Ukrainian].

Pospelov, D. A. (1986). Situatcionnoe upravlenie: teoriia i praktika. Moscow: Science, 288 p. [In Russian].

Pospelov, D. A. (1989). Modelirovanie rassuzhdenii. Moscow: Radio and communication, $184 \mathrm{p}$. [In Russian].

Poturaev, V. N., \& Belobrov, V. I. (1989). Analiz dinamiki mekhanicheskikh sistem. Kiev: Higher school, 151 p. [In Russian].

Printcipy. (1972). Mekhanizmy i printcipy tcelenapravlennogo povedeniia. Moscow: Science, 295 p. [In Russian].

Ragulskie, K. N. (Ed.). (1987). Shirokopolosnye vibroudarnye generatory mekhanicheskikh kolebanii. Leningrad, 75 p. [In Russian].

Roberts, F. S., \& Geiman, A. I. (Ed.). (1986). Diskretnye matematicheskie modeli s prilozheniiami $k$ sotcialnym biologicheskim i ekologicheskim zadacham. Moscow: Science, 496 p. [In Russian].

Roitman, A. G. (1990). Preduprezhdenie avarii zhilykh zdanii. Moscow: Stroiizdat, 240 p. [In Russian].

Shapar, A. H., \& Mikheev, O. V. (2018). Kontseptualni pidkhody do rozuminnia protsesiv antropohennoi destabilizatsii ekolohichnykh system. Bulletin of the National Academy of Science of Ukraine, 3, 56-66. [In Ukrainian].

Sikora, L. (1999). Informatsiino-resursna kontseptsiia identyfikatsii $i$ syntezu robastnykh system upravlinnia. Lviv: TsSD, 372 p.

Sikora, L. S. (1988). Lazerni informatsiino-vymiriuvalni systemy dlia upravlinnia tekhnolohichnymy protsesamy TSS. (Vol. 2). Lviv: Kameniar, TsSD "EBTES", 445 p. [In Ukrainian].
Sikora, L. S. (1998). Systemolohiia pryiniattia rishen ta upravlinnia $v$ skladnykh tekhnolohichnykh strukturakh. Lviv: Kameniar, 453 p. [In Ukrainian].

Sikora, L. S. (2001). Robastni ta informatsiini kontseptsii v protsedurakh syntezu systemy upravlinnia. Lviv, 577 p. [In Ukrainian].

Sikora, L. S., Medykovskyi, M. D., \& Hrytsyk, V. V. (2002). Perspektyvni informatsiini tekhnolohii v systemakh avtomatychnoho upravlinnia enerhoaktyvnymy obiektamy vyrobnychykh struktur. Lviv: DNDI, 416 p. [In Ukrainian].

Skurikhin, V. I., Kvachev, V. G., Valkman, Iu. R., \& Iakovenko, L. P. (1990). Informatcionnye tekhnologii v ispytaniiakh slozhnykh obektov: metody i sredstva. Kiev: Scientific thought, 320 p. [In Russian].

Smoliakov, E. R. (1986). Ravnovesnye modeli pri nesovpadaiushhikh interesakh uchastnikov. Moscow: Science, 221 p. [In Russian].

Sviridov, V. V. (1978). Kontrol v slozhnykh sistemakh. Moscow: Knowledge, 61 p. [In Russian].

Tikhonov, V. I. (1970). Vybrosy sluchainikh protcessov. Moscow: Science, 392 p. [In Russian].

Timochenko, S. P. (1967). Kolebaniia v inzhenernom dele. Moscow: Science, 444 p. [In Russian].

Timoschenko, S. P. (1955). Vibration Problems in Enginiring. New York.

Timoshenko, S. P. (1967). Kolebaniia v inzhenernom dele. Moscow: Science, 444 p. [In Russian].

Tivilov, T. A. (Ed.). (1988). Dynamics of High-speed Vehicles. Transport, 274, 215. [In Russian].

Tkachuk, R. L., \& Sikora, L. S. (2010). Lohiko-kohnityvni modeli formuvannia upravlinskykh rishen intehrovanymy systemamy $v$ ekstremalnykh umovakh. Lviv: Liha-Pres, 404 p. [In Ukrainian].

Vasylenko, V. A. (2017). Heneza, zmist i shliakhy realizatsii kontseptsii mizhnarodnoi ekolohichnoi bezpeky. Bulletin of the $\mathrm{Na}$ tional Academy of Science of Ukraine, 7, 89-96. [In Ukrainian].

Volik, B. M. (Ed.). (1985). Metody analiza i sinteza struktur upravliaiushhikh sistem. Moscow: Energoatomizdat, 296 p. [In Russian].

L. S. Sikora', N. K. Lysa', V. I. Sabat ${ }^{2}$, B. I. Fedyna', V. I. Kunchenko-Kharchenko ${ }^{4}$

${ }^{l}$ Lviv Polytechnic National University, Lviv, Ukraine

${ }^{2}$ Ukrainian Academy of Printing, Lviv, Ukraine

${ }^{3}$ Cherkasy State Technological University, Cherkasy, Ukraine

\section{LASER AND INFORMATION TECHNOLOGIES FOR CONTROLLING DYNAMIC DISPLACEMENTS OF SPATIAL STRUCTURES OF OBJECTS UNDER THE INFLUENCE OF ACTIVE TECHNOGENIC AND NATURAL RISK FACTORS FOR ACCIDENTS}

At the present stage of the development of science, for technological and technogenic energy-intensive systems, systematic methods of identification of structure, dynamics, and risk assessment are developed, while for spatial objects this problem is not fully solved. This applies to the construction and operation of the objects with a spatially distributed structure such as bridges, large pavilions, high-rise buildings, aggregate lines on a common foundation for colour printing, which are subject to a large dynamic, non-uniform load-capacity, operating over a long period of operation. Their destruction with the combined action of dynamic and static heterogeneous flow factors in time of high power leads to the accidents and human losses. The main factor that leads to cognitive errors in the design of spatial structures is that experts in the design process do not fully take into account the concepts of physical force, power and physical energy factors with stream random structure. In this aspect, the problem of dynamic structural stability under the influence of factors with a stochastic structure drew attention to Y.P. Drahan, introducing the notion of "stochastic process of finite energy" and "finite power of flows (sequences) of active physical force actions". Under certain conditions, the complex action of force factors leads to the emergence of solutions, i.e., the formation of the peak of energy and power at a certain time in the weakest node of the structure that destroys it. If the designer, by virtue of his cognitive abilities and level of knowledge, does not take into account the energetic nature of the factors as destructive forces, then this leads to the destruction of infrastructure objects (the bridge in Genoa, Italy 2015, built in 1967) devastating floods, fires, transport disasters, tsunami. As for the steel construction bridges in the USA (New York), built on the basis of the methods of vibration calculations by S. Tymoshenko, they are operated for more than 100 years, with appropriate technical maintenance. The assessment of the vibrational stability of spatial structures, both existing and new projects, remains a complex control problem that is not resolved to the fullest, and therefore the development of integrated intellectual methods for designing and controlling their state is relevant. The intensive development of infrastructure, both social and technogenic, results from the impact of transport flows, power plants, harmful emissions, to the growth of force environmental load on spatial structures, corrosion of metal components, and the growth of vibrational effects on elements of objects. Further development of such negative processes leads to a decrease in the strength of structures, their stability, operational reliability and destruction. Reducing the quality of bearing structures, due to neglected negative influences, enables forecasting the moment of emergency situations. Therefore, the development of methods for remote control of vibrations of spatial elements of bearing structures is the main problem for various industries.

Keywords: construction; vibration; laser; signal; dynamic processes; active factors; data; system; information; project; risks; accident.

Науковий вісник НЛТУ України, 2019, т. 29, № 6

Scientific Bulletin of UNFU, 2019, vol. 29, no 6135 